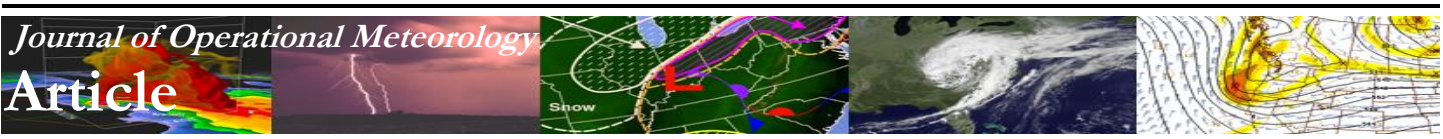

\title{
Warm-Season Thunderstorm Development as a Function of Vertical Distribution of Relative Humidity in the Lower Rio Grande Valley of Texas
}

\author{
JUSTIN G. GIBBS \\ NOAA/National Weather Service, Warning Decision Training Division, Norman, Oklahoma
}

DOUGLAS A. BUTTS JR.

NOAA/National Weather Service Forecast Office, Mobile, Alabama

(Manuscript received 20 February 2015; review completed 3 September 2015)

\begin{abstract}
Weakly forced large-scale weather patterns often dominate the warm season (June-September) in the Lower Rio Grande Valley of Texas. In this regime, forecasting thunderstorm development is often tied to very subtle features, making this task particularly challenging. There appears to be a link between middleand lower-level moisture content (specifically at 850-700 hPa) and the frequency of thunderstorm development, with little variability in many other meteorological variables. Higher $850-700$-hPa relative humidity values link to much higher rates of thunderstorm development.
\end{abstract}

\section{Introduction}

The location of the Lower Rio Grande Valley of Texas (Fig. 1) presents unique weather forecasting challenges. A relatively sparse observational network exists to the east across the Gulf of Mexico and southwest across northern Mexico. As such, it can be quite difficult to accurately assess current atmospheric conditions. Additionally, despite being located in an active sea breeze zone, the region experiences significantly lower amounts of rainfall on average than other coastal cities in the southeastern United States (Table 1). Part of this dryness can be attributed to nearby terrain, primarily the Sierra Madre Oriental and adjacent Mexican Plateau. Southwesterly winds downsloping across these features tend to significantly warm and dry air in the 900-700-hPa layer over the Lower Rio Grande Valley. An example of such can be seen in Fig. 2 where strong southwesterly winds produced a significant subsidence inversion at 900 $\mathrm{hPa}$. In the summer months, with the polar jet well north of the region resulting in weaker synoptic-scale forcing, wind speeds remain much lower in this layer. As a result, such an advection-related inversion rarely develops. This, coupled with no obvious limitations of near-surface moisture or lack of sea breeze convergence, makes the stark difference in annual precipitation intriguing.

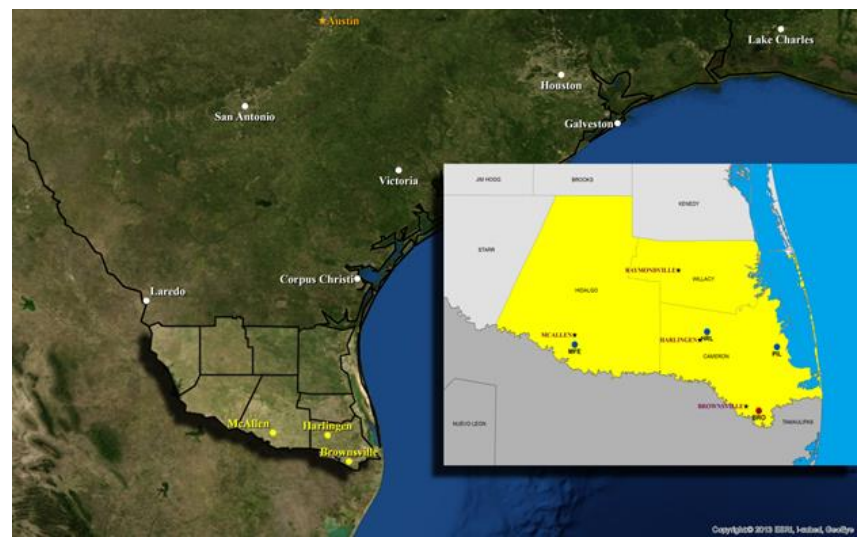

Figure 1. Map highlighting the county warning area of the National Weather Service in Brownsville and its location relative to other major cities, with the study region for this paper highlighted in the inset. The Brownsville/South Padre Island International Airport (BRO), marked in red, serves as one of the surface observation sites, upper-air site, and location of the radar used for vertical wind profile analysis. Locations of Valley International Airport (HRL), McAllen-Miller International Airport (MFE), and Port Isabel-Cameron County Airport (PIL) are marked in blue. Click image for an external version; this applies to all figures hereafter. 
Table 1. Mean annual precipitation for 2000-2014 at cities in the southeastern United States that are located a similar distance from the Atlantic Ocean or Gulf of Mexico as the Brownsville, TX, climate station [National Oceanic and Atmospheric Administration (NOAA) 2014].

\begin{tabular}{|l|l|}
\hline City & Mean Monthly Precipitation [cm (in)] \\
\hline Brownsville, TX & $69.70(27.44)$ \\
\hline Houston, TX & $126.23(49.70)$ \\
\hline Mobile, AL & $161.95(63.76)$ \\
\hline Tampa, FL & $117.60(46.30)$ \\
\hline West Palm Beach, FL & $158.24(62.30)$ \\
\hline
\end{tabular}

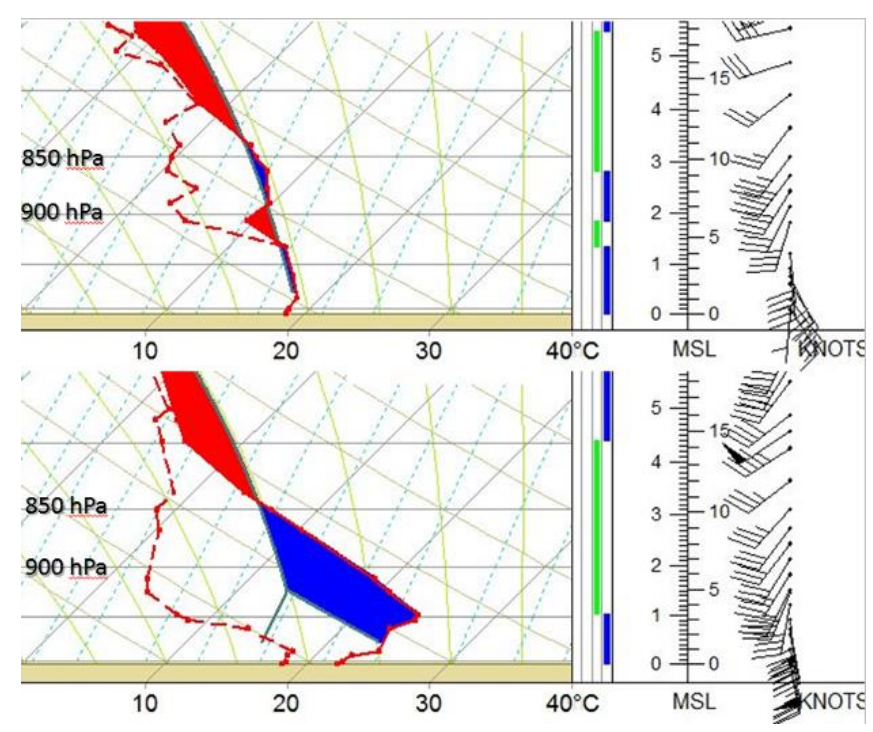

Figure 2. Skew $T-\log p$ thermodynamic diagrams from the surface to $600 \mathrm{hPa}$ comparing Brownsville, TX, radiosonde observations for (top) 1200 UTC 8 January 2013 and (bottom) 0000 UTC 9 January 2013. Data obtained from the University of Wyoming (weather.uwyo.edu/upperair/sounding.html).

This study examined five years of thunderstorm reports and observational data, finding that many thunderstorms in the region form in nonfrontal or weakly forced environments (e.g., no strong thermal advection, differential vorticity advection, or convergence or divergence). Thunderstorms generated in these environments present a unique challenge that makes accurate diagnosis of atmospheric instability very important (Jacovides and Yonetani 1990). Weak forcing, as well as a paucity of in-situ observations over Mexico and the Gulf of Mexico, also present special challenges to producing reliable numerical model guidance (Kalnay 2003). For the months of June-September 2009-2012, GFS MOS was the most reliable guidance available to forecasters. Mean Brier scores during this period were 0.09 . However, accuracy decreased to 0.439 through the first $24 \mathrm{~h}$ of the forecast when considering only forecasts in which precipitation occurred (NOAA 2015b). Newer convection-allowing models, such as the high-resolution Weather Research and Forecasting model or High Resolution Rapid Refresh, are promising, but robust statistical evidence to their effectiveness in forecasting weakly forced convection is still being ascertained. In addition, these models have a limited temporal range. With numerous threats posed by thunderstorms, achieving a high degree of thunderstorm forecast accuracy at the largest lead times possible is desirable. The challenges of forecasting in this region is highlighted by examining a series of cases that show little variation in surface dewpoint, temperature, and midlevel temperature and lapse rates between thunderstorm and non-thunderstorm days. Closer examination yields a relationship between the depth of tropical moisture (as measured by relative humidity in the $850-700-\mathrm{hPa}$ layer) and the probability of thunderstorm development in a weakly forced environment.

\section{a. Literature review}

Cumulus cloud processes and any subsequent development into deep, moist convection and thunderstorms have been studied extensively. Holton (2004) defined conditional instability as a state where the lapse rate lies between dry adiabatic and pseudoadiabatic values. Conditional instability requires saturation of a lifted air parcel to render it statically unstable. The latent heat of a rising saturated parcel lowers its effective lapse rate, keeping it warmer than the surrounding atmospheric air during ascent. Conditional instability can be calculated as convective available potential energy (CAPE). This calculation, however, does not consider parcel entrainment, which reduces parcel buoyancy (Holton 2004). Doswell and Markowski (2004) explored the relative quantity of buoyancy by considering vertical motion as a function of the difference between the parcel and environmental temperature, as well as the importance of continued relative buoyancy in sustaining a convective updraft. Lacis and Hansen (1974) parameterized the rate at which water vapor absorbs incoming solar radiation. Their work allows us to compare rates of midlevel and low-level diurnal warming in observed soundings and determine if insolation is the likely cause. Highly variable rates of warming between cloud-free, dry air and saturated, cloudy air also were discussed.

Cumulus clouds distribute heat away from an excessively warming boundary layer (Grant 2001). As development and vertical growth occurs, heat is transferred to the surrounding environment through con- 
densation. Weak lapse rates in the cloud-growth layer increase the likelihood of clouds becoming negatively buoyant when encountering dry air. If the cloud encounters and entrains much drier air, it can gradually lose buoyancy until becoming negatively buoyant (Arakawa and Schubert 1974; Derbyshire et al. 2004; de Rooy et al. 2013). Once a developing cloud parcel becomes negatively buoyant, it detrains the remaining moisture. This evaporation generates some cooling, but because the parcel is now negatively buoyant, it sinks as a downdraft, providing subsidence and additional warming to the surrounding environment below that layer of cooling (Yanai and Johnson 1993). Some of these drier downdrafts may then descend into the mixed layer and bring drier air into the relatively moist environment (Derbyshire et al. 2004). Mechanical mixing then transports this drier air closer to the surface, increasing the stability of parcels based near the surface (Holton 2004).

De Rooy et al. (2013) showed that the rate at which a parcel entrains drier atmospheric air is a function of the value of local atmospheric relative humidity. This means that the drier the surrounding atmospheric air, the more that dry air will be entrained into the cloud. Derbyshire et al. (2004) found that detraining cumulus clouds produce less condensation. This results in less parcel warming and causes updrafts to lose buoyancy in a marginally unstable environment. Siebesma (1998) demonstrated that cumulus entrainment and detrainment rates are relative to the total cloud surface area. This implies that a smaller cumulus cloud would entrain or detrain air from the surrounding environment at a much higher relative rate per unit mass than a larger cloud. Without strong and organized large-scale forcing (e.g., front, warm layer advection, differential positive vorticity advection), cumulus development may produce a smaller total area of cloud (Byers and Braham 1949), making the clouds more susceptible to dry air entrainment (Siebesma 1998).

The above combined studies highlight important aspects of cumulus cloud and thunderstorm development. Although these are applicable globally, they appear to be especially relevant over the Lower Rio Grande Valley of Texas. Persistently weak mid- and lower-level lapse rates place a premium on higher relative humidity values to sustain parcel buoyancy through reduction of the parcel lapse rate via latent heat release. Traditional calculations of CAPE, which do not consider parcel entrainment of dry atmospheric air and the corresponding increase of the parcel lapse rate (Holton 2004), may overestimate parcel buoyancy in such regimes where the ascending theoretical parcel is only slightly warmer than the surrounding atmosphere.

\section{Data and methods}

Data from April 2010 to April 2015 were acquired from the National Climatic Data Center (NOAA 2015a) for four Automated Surface Observing System (ASOS) platforms across the region. As shown in Fig. 1, these locations (all in Texas) include Port IsabelCameron County Airport (PIL) near Bayview, Brownsville/South Padre Island International Airport (BRO) in Brownsville, Valley International Airport (HRL) in Harlingen, and McAllen-Miller International Airport (MFE) in McAllen. Using these data, thunderstorm days were determined using the NOAA Preliminary Monthly Climate Data Product (CF6) (NOAA 2015a). With the exception of PIL, all locations are augmented by observers from 1100 to 0400 UTC. The locations are only separated by approximately $40 \mathrm{~km}(25 \mathrm{mi})$ and are believed to provide a representative picture of thunderstorm occurrence in the area. To further ensure thunderstorms actually occurred on the days reported, archived radar data from the University Corporation for Atmospheric Research (UCAR, www2.mmm.ucar.edu/imagearchive/) were used, using a 50-dBZ composite reflectivity threshold. This $50-\mathrm{dBZ}$ threshold was determined by considering a warmer environment than what was given by Vincent et al. (2003). Subsequently, 193 thunderstorm days - or days in which at least one thunderstorm was reported by at least one ASOS platform-were identified (Fig. 3).

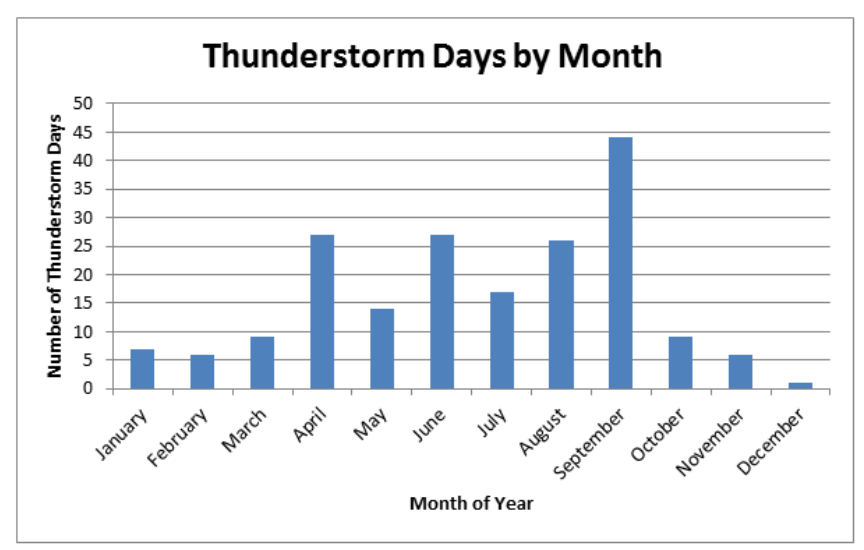

Figure 3. Number of days each month that thunderstorms were reported by one or more of the Lower Rio Grande Valley ASOS platforms (BRO, HRL, MFE, or PIL) from April 2010 to April 2015 (NOAA 2015a). 
Data were further stratified to identify days with weak synoptic-scale forcing (e.g., the absence of cold fronts, strong warm advection, or significant midlevel differential positive vorticity advection) using surface and upper-level data from Plymouth State University's archive (vortex.plymouth.edu/u-make.html). No tropical cyclones appeared to contribute to thunderstorm development during the time of study. After stratification, 63 thunderstorm cases, occurring between 1200 and 0000 UTC, were available for analysis during the 1 June to 30 September warm season. Prior to and after these dates, thunderstorm cases frequently were associated with stronger synoptic-scale forcing. Reanalysis of 250-hPa wind speeds (www.esrl.noaa. gov/psd/data/gridded/data.ncep.reanalysis.html) shows stronger winds associated with the polar jet stream moving well north of the study region from June through September. This position of the jet is consistent with the study's finding of minimal synoptic-scale forcing during the 1 June to 30 September period.

Candidates for non-thunderstorm days during the study period were identified using the CF6 (NOAA 2015a) product. After determining days in which no thunder was reported at any ASOS platform used in this study, candidate days were cross-checked with UCAR's radar archive to ensure reflectivity values remained below $50 \mathrm{dBZ}$ across the study region between 1200 and 0000 UTC. This cross-check was performed to guard against contamination of the dataset by an ASOS failing to report thunder. Rawinsonde observations (RAOBs) on non-thunderstorm days then were analyzed for characteristics that are unfavorable for developing deep, moist convection (e.g., strong subsidence drying, excessive terrain-induced capping). If no limiting attributes were present, the 1200 UTC RAOB's surface temperature and dewpoint were modified to the day's 1900 UTC surface observation at BRO. This hour was chosen subjectively as a time when surface temperature and dewpoint values often were at their highest combined values - prior to seabreeze front cooling and surface dewpoint values falling because of mixing. If the modified soundings then suggested positive, uncapped CAPE using a 100$\mathrm{hPa}$ mixed-layer parcel method, it was included as a non-thunderstorm day case. Dry air entrainment was not considered in the drawing of the theoretical parcel line (Holton 2004). After stratification, 63 non-thunderstorm days were selected during the five-year period.

For the selected days, temperature and relative humidity data from 850,700 , and $500 \mathrm{hPa}$ were gath- ered for the 1200 and 0000 UTC RAOBs. The 12-h change of each variable was calculated for each level, as was the average value of each variable for both thunderstorm and non-thunderstorm days.

A narrow layer of daytime warming was observed in some cases during the course of the study. In an attempt to determine if cumulus convection contributed to this warming and what role the warming played in whether or not thunderstorms developed, additional analysis was conducted on 14 non-thunderstorm cases displaying surface-900-hPa relative humidity $>80 \%$ and nighttime cooling and daytime warming of $\geq 1{ }^{\circ} \mathrm{C}$ in the 900-700-hPa layer. The vertical location of maximum warming between 1200 and 0000 UTC in the 900-700-hPa layer was identified using the closest available data level between the two observations. The BRO ASOS observations then were analyzed for reports of cloud development below $2.1 \mathrm{~km}(6800 \mathrm{ft})$ the region thought to be favorable for cumulus cloud development - through the late morning and afternoon, and the height of the cloud bases were documented.

Finally, the surface wind speed at 1600 UTC, which would allow for approximately four hours of daytime heating, was collected for both thunderstorm and non-thunderstorm days for the 55 days within the study between 2010 and 2013. This time was selected, primarily for convenience, to attempt to capture the period where towering cumulus would often begin to transition to cumulonimbus clouds. The velocity azimuth display wind profile (VWP) from the BRO Weather Surveillance Radar-1988 Doppler radar (www.ncdc.noaa.gov/oa/radardata.html) was used to calculate approximate wind speeds at the 1-, 2-, and 3$\mathrm{km}$ levels to quantify both wind speed and approximate shear at the time cumulus clouds typically started to develop. The root mean square error (RMSE) of the wind speed within VWP data was $<2 \mathrm{~m} \mathrm{~s}^{-1}$ (4 kt) for all observations, indicating the measurements represented existing conditions. The RMSE is calculated using a horizontal average of radial velocities from the previous volume scan and making a prediction about the following scan by assigning velocity values to a sine wave function (Rinehart 1997).

Pearson's chi-squared $\left(\chi^{2}\right)$ test for independence (Rao 2002) was used to determine statistical significance and independence between numerous variables within the study. The data were stratified by significant values, such as whether or not thunderstorms occurred, and then compared against threshold values, such as relative humidity values above or below a 
certain value. Once the data were compiled, a $\chi^{2}$ value was calculated and compared to a $\chi^{2}$ distribution table to determine the probability that values were dependent ( $p$ value). Values of $\chi^{2}$ corresponding to a $p$ value $<0.05$ were considered dependent.

\section{Discussion and analysis}

Forecasting summer convection using methods from simple parcel theory (Holton 2004) yields poor results in the Lower Rio Grande Valley. The reasons appear to be related to relative parcel buoyancy concerns addressed by Doswell and Markowski (2004) and parcel entrainment of dry air above the boundary layer (Holton 2004). Thunderstorms often fail to develop even when uncapped, positive, surface-based and 100-hPa mixed-layer CAPE exists on modified 1200 UTC RAOBs and weak sea-breeze convergence develops across the study region. Consistent diurnal warming and drying also occur between 850 and 750 $\mathrm{hPa}$ on non-thunderstorm days, which may increase capping aloft. This is greater than what would be expected from water vapor absorption of incoming solar radiation alone (Lacis and Hansen 1974). Figure 4 illustrates this process between 23 and 25 July 2012.

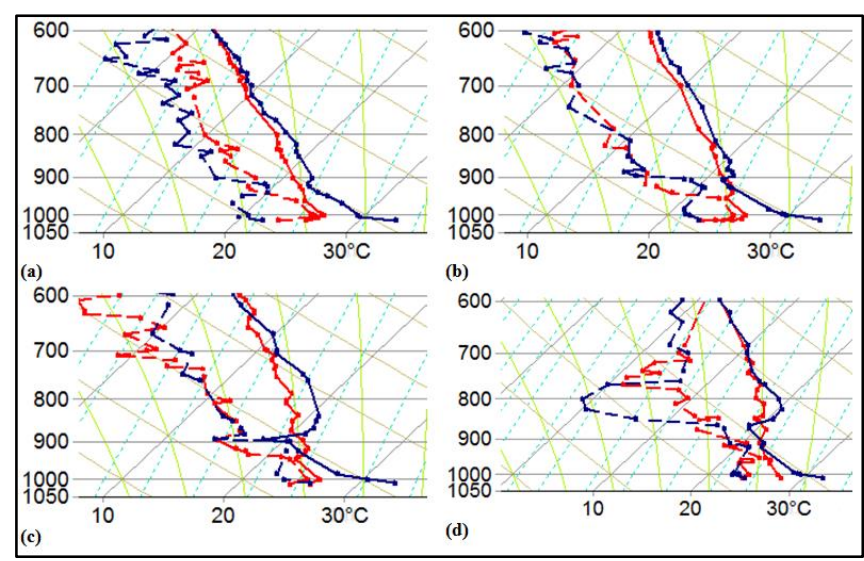

Figure 4. Skew $T-\log p$ thermodynamic diagrams from the surface to $600 \mathrm{hPa}$ comparing $1200 \mathrm{UTC}$ (colored red) and $0000 \mathrm{UTC}$ (colored blue) BRO RAOBs from (a) 23 July 2012, (b) 24 July 2012, (c) 25 July 2012, and (d) 26 July 2012. Data courtesy of the University of Wyoming.

\section{a. Comparison of meteorological variables on thun- derstorm and non-thunderstorm days}

Table 2 shows that surface moisture and daytime heating were available for both thunderstorm and nonthunderstorm day cases. Mean surface temperature and dewpoint at 1200 UTC for both thunderstorm and nonthunderstorm days were similar. Mean temperature at
$500 \mathrm{hPa}$ also varied little, with values near $-6^{\circ} \mathrm{C}$ observed for both thunderstorm and non-thunderstorm days. Surface temperatures increased to more than $30^{\circ} \mathrm{C}$ in all cases (not shown). At least some positive, uncapped, mixed-layer CAPE existed on rawinsonde observations modified for the 1900 UTC temperature and dewpoint for all days within the study domain.

Table 2. Comparison of 1200 UTC mean surface temperature, 500-hPa temperature, and surface dewpoint for 63 thunderstorm and 63 non-thunderstorm days from June to September. Data derived from BRO RAOBs.

\begin{tabular}{|l|c|c|}
\hline & $\begin{array}{c}\text { Non-thunderstorm } \\
\text { Days (63) }\end{array}$ & $\begin{array}{c}\text { Thunderstorm Days } \\
(\mathbf{6 3})\end{array}$ \\
\hline $\begin{array}{l}\text { 1200 UTC Surface } \\
\text { Temperature }\left({ }^{\circ} \mathrm{C}\right)\end{array}$ & 25.5 & 25.3 \\
\hline $\begin{array}{l}\text { 1200 UTC 500-hPa } \\
\text { Temperature }\left({ }^{\circ} \mathrm{C}\right)\end{array}$ & -5.8 & -6.2 \\
\hline $\begin{array}{l}\text { 1200 UTC Surface } \\
\text { Dewpoint }\left({ }^{\circ} \mathrm{C}\right)\end{array}$ & 20.4 & 20.5 \\
\hline
\end{tabular}

Weak atmospheric lapse rates generally were present in all cases (Table 3 ). Conducting Pearson's $\chi^{2}$ test for independence (Rao 2002) for multiple lapse rate values on thunderstorm or non-thunderstorm days produced no $p$ value $<0.380$ in the $700-500-\mathrm{hPa}$ layer. This implies independence of the variables at multiple values. Table 4 shows one permutation of lapse rate variables compared with thunderstorm or non-thunderstorm days in the dataset. In the 850-700-hPa layer, we are able to reject independence of the variables (Table 5). Interestingly, however, there existed a tendency for more thunderstorms to occur on days when lapse rates in this layer were slightly weaker. This tendency is presumed to be related to the warm core structure of African easterly waves moving across the lower Texas coast and their propensity to increase precipitation coverage (Hopsch et al. 2010). This suggests that variations in midlevel temperatures, as well as surface moisture and heating, were not the primary factors in determining whether or not thunderstorms developed during the period of study.

Based on studies by Cotton and Tripoli (1978) and Hinkleman et al. (2005), wind speed and shear also were examined from the surface to $3 \mathrm{~km}$ above ground level for cases between 2011 and 2014 (inclusive). Shear calculations were limited to speed shear, as no days indicated more than $10^{\circ}$ of directional change when wind speeds were $>2.6 \mathrm{~m} \mathrm{~s}^{-1}(5 \mathrm{kt})$. Table 6 shows very little difference between observed surface wind speeds or layer speed shear when 1600 UTC values are examined for thunderstorm and non-thunderstorm days. Mean surface wind direction was $140^{\circ}$ 
Table 3. Comparison of 1200 UTC mean 850-700- and 700-500$\mathrm{hPa}$ lapse rates for thunderstorm and non-thunderstorm days from June to September. Data derived from BRO RAOBs.

\begin{tabular}{|l|c|c|}
\hline & $\begin{array}{c}\text { Non-thunderstorm } \\
\text { Days }\end{array}$ & $\begin{array}{c}\text { Thunderstorm } \\
\text { Days }\end{array}$ \\
\hline $\begin{array}{l}\text { 1200 UTC } 850-700-\mathrm{hPa} \\
\text { Lapse Rate }\left({ }^{\circ} \mathrm{C} \mathrm{km}^{-1}\right)\end{array}$ & 5.9 & 5.9 \\
\hline $\begin{array}{l}\text { 1200 UTC } 700-500-\mathrm{hPa} \\
\text { Lapse Rate }\left({ }^{\circ} \mathrm{C} \mathrm{km}^{-1}\right)\end{array}$ & 5.7 & 5.5 \\
\hline
\end{tabular}

Table 4. Number of thunderstorm and non-thunderstorm days from June to September in which the 1200 UTC 700-500-hPa lapse rate was $\geq 5.9^{\circ} \mathrm{C} \mathrm{km}^{-1}$ and $<5.9^{\circ} \mathrm{C} \mathrm{km}^{-1}$. Results of Pearson's $\chi^{2}$ test are $\chi^{2}=0.514$, $\mathrm{df}=1$, and $p=0.473$. Data from BRO RAOBs.

\begin{tabular}{|c|c|c|}
\hline & $\begin{array}{c}\text { 700-500-hPa Laspe } \\
\text { Rate } \geq 5.9^{\circ} \mathrm{C} \mathrm{km}^{-1}\end{array}$ & $\begin{array}{c}\text { 700-500-hPa Laspe } \\
\text { Rate }<5.9^{\circ} \mathrm{C} \mathrm{km}^{-1}\end{array}$ \\
\hline $\begin{array}{l}\text { Thunderstorms } \\
\text { Occurred }\end{array}$ & 33 & 30 \\
\hline $\begin{array}{l}\text { No Thunderstorms } \\
\text { Occurred }\end{array}$ & 37 & 26 \\
\hline
\end{tabular}

Table 5. Same as Table 4 except for the $850-700$-hPa lapse rate was $\geq 5.8^{\circ} \mathrm{C} \mathrm{km}^{-1}$ and $<5.8^{\circ} \mathrm{C} \mathrm{km}^{-1}$. Results of Pearson's $\chi^{2}$ test are $\chi^{2}=8.76$, df $=1$, and $p=0.003$.

\begin{tabular}{|c|c|c|}
\hline & $\begin{array}{c}\text { 850-700-hPa Laspe } \\
\text { Rate } \geq 5.8^{\circ} \mathrm{C} \mathrm{km}^{-1}\end{array}$ & $\begin{array}{c}\text { 850-700-hPa Laspe } \\
\text { Rate }<5.8^{\circ} \mathrm{C} \mathrm{km}^{-1}\end{array}$ \\
\hline $\begin{array}{l}\text { Thunderstorms } \\
\text { Occurred }\end{array}$ & 15 & 48 \\
\hline $\begin{array}{l}\text { No Thunderstorms } \\
\text { Occurred }\end{array}$ & 31 & 32 \\
\hline
\end{tabular}

Table 6. Mean surface wind speed taken at 1600 UTC from the BRO ASOS, along with the 1-, 2- and 3-km mean wind speeds, and $0-3-\mathrm{km}$ shear (change in wind speed through $3 \mathrm{~km}$ ) as determined from the BRO WSR-88D VWP. Data are divided into thunderstorm and non-thunderstorm days from June to September from 2011 to 2014 .

\begin{tabular}{|c|c|c|}
\hline & Thunderstorm Days & $\begin{array}{c}\text { Non-Thunderstorm } \\
\text { Days }\end{array}$ \\
\hline $\begin{array}{c}\text { Surface Wind Speed } \\
{\left[\mathrm{m} \mathrm{s}^{-1}(\mathrm{kt})\right]}\end{array}$ & $5.14(10)$ & $5.14(10)$ \\
\hline $\begin{array}{c}\text { 1-km Wind Speed } \\
{\left[\mathrm{m} \mathrm{s}^{-1}(\mathrm{kt})\right]}\end{array}$ & $6.67(13)$ & $7.20(14)$ \\
\hline $\begin{array}{c}\text { 2-km Wind Speed } \\
{\left[\mathrm{m} \mathrm{s}^{-1}(\mathrm{kt})\right]}\end{array}$ & $7.71(15)$ & $7.71(15)$ \\
\hline $\begin{array}{c}\text { 3-km Wind Speed } \\
{\left[\mathrm{m} \mathrm{s}^{-1}(\mathrm{kt})\right]}\end{array}$ & $8.23(16)$ & $7.71(15)$ \\
\hline $\begin{array}{c}\text { 0-3-km Shear } \\
\text { Speed }\left[\mathrm{m} \mathrm{s}^{-1}(\mathbf{k t})\right]\end{array}$ & $3.00(6)$ & $2.50(5)$ \\
\hline
\end{tabular}

for both thunderstorm and non-thunderstorm days. When testing multiple shear values against thunderstorm and non-thunderstorm days using Pearson's $\chi^{2}$ test for independence, no test produced a $p$ value $<0.50$. This implies independence between all values of these two sets of variables and suggests low-layer wind shear variations also were not primary factors in determining whether thunderstorms developed. With no significant differences in wind direction, surface moisture, and surface temperature, the day-to-day changes in the strength of sea breeze convergence also were not likely a primary factor (Keyser et al. 1988).

The strongest discriminator between thunderstorm and non-thunderstorm days appeared to be the distribution of moisture throughout the lower free troposphere, particularly the $850-700-\mathrm{hPa}$ layer. Table 7 shows 1200 UTC mean relative humidity at 850,700 , and $500 \mathrm{hPa}$, as well as for the combined $850-700-\mathrm{hPa}$ mean. The largest mean difference was at $700 \mathrm{hPa}$ (24\%), but a $20 \%$ difference also existed at $850 \mathrm{hPa}$. Tables 8 and 9 show the number of thunderstorm days and non-thunderstorm days split by 1200 UTC 850and $700-\mathrm{hPa}$ average relative humidity values, respectively, $\geq 65 \%$ and $<65 \%$. Table 10 shows the $500-\mathrm{hPa}$ relative humidity values split using a criterion of $48 \%$. Pearson's $\chi^{2}$ test for independence produces a $p$ value of $<0.0004$ for all three tables, producing very high confidence the variables are dependent. This suggests a relationship between relatively humidity values at these levels and the development of thunderstorms.

The higher incidence of thunderstorms on days when greater mid- and lower-tropospheric relative humidity values are observed is believed to be related to two primary factors. First, persistent large-scale subsidence, commonly present over the area from 1 June to 30 September, results in $850-700-\mathrm{hPa}$ and $700-500-\mathrm{hPa}$ atmospheric lapse rates very close to the saturation adiabatic lapse rate. This yields less relative buoyancy for ascending parcels. These conditions vary little from day to day. Lower- and mid-tropospheric relative humidity, however, is more variable, because it is tied to subtle changes in moisture advection and large-scale subsidence. Parcels that initially become saturated, but then encounter and entrain drier air during their ascent, fail to release enough latent heat through condensation to remain positively buoyant amid the weak atmospheric lapse rates. Alternately, parcels that entrain less dry air produce more condensation and thus maintain buoyancy (Holton 2004). The persistent combination of abundant surface heating and moisture makes mid-tropospheric relative humidity a strong signal with regard to thunderstorm variability.

Consistent daytime warming in the $850-700-\mathrm{hPa}$ layer also was apparent in rawinsonde observations. Table 11 shows that this warming is stronger on nonthunderstorm days, which likely can be attributed to direct heating from insolation (Lacis and Hansen 1974), latent heat of condensation from excess heat being transported away from the boundary layer, and 
Table 7. Mean 1200 UTC relative humidity at selected levels separated by thunderstorm and non-thunderstorm days from June to September. Data derived from BRO RAOBs.

\begin{tabular}{|c|c|c|}
\hline $\begin{array}{c}\text { Level or Layer } \\
\text { (hPa) }\end{array}$ & $\begin{array}{c}\text { Relative Humidity: } \\
\text { Thunderstorm Days }\end{array}$ & $\begin{array}{c}\text { Relative Humidity: Non- } \\
\text { Thunderstorm Days }\end{array}$ \\
\hline 850 & $78 \%$ & $58 \%$ \\
\hline 700 & $68 \%$ & $44 \%$ \\
\hline 500 & $56 \%$ & $36 \%$ \\
\hline $850-700$ & $73 \%$ & $51 \%$ \\
\hline
\end{tabular}

Table 8. Number of thunderstorm and non-thunderstorm days from June to September in which the 1200 UTC 850-hPa average relative humidity was $\geq 65 \%$ and $<65 \%$. Results of Pearson's $\chi^{2}$ test are $\chi^{2}=50.103, \mathrm{df}=1$, and $p<0.0004$. Data from BRO RAOBs.

\begin{tabular}{|l|c|c|}
\hline & $\begin{array}{c}\text { 850-hPa Relative } \\
\text { Humidity } \geq \mathbf{6 5 \%}\end{array}$ & $\begin{array}{c}\text { 850-hPa Relative } \\
\text { Humidity }<\mathbf{6 5 \%}\end{array}$ \\
\hline $\begin{array}{l}\text { Thunderstorms } \\
\text { Occurred }\end{array}$ & 57 & 6 \\
\hline $\begin{array}{l}\text { No Thunderstorms } \\
\text { Occurred }\end{array}$ & 18 & 45 \\
\hline
\end{tabular}

Table 9. Same as Table 8 except for the $700-\mathrm{hPa}$ average relative humidity. Results of Pearson's $\chi^{2}$ test are $\chi^{2}=64.874$, df $=1$, and $p$ $<0.0004$.

\begin{tabular}{|l|c|c|}
\hline & $\begin{array}{c}\text { 700-hPa Relative } \\
\text { Humidity } \geq \mathbf{6 5 \%}\end{array}$ & $\begin{array}{l}\text { 700-hPa Relative } \\
\text { Humidity }<\mathbf{6 5 \%}\end{array}$ \\
\hline $\begin{array}{l}\text { Thunderstorms } \\
\text { Occurred }\end{array}$ & 51 & 12 \\
\hline $\begin{array}{l}\text { No Thunderstorms } \\
\text { Occurred }\end{array}$ & 6 & 57 \\
\hline
\end{tabular}

Table 10. Same as Table 8 except for the $500-\mathrm{hPa}$ average relative humidity was $\geq 48 \%$ and $<48 \%$. Results of Pearson's $\chi^{2}$ test are $\chi^{2}=$ 17.227, $\mathrm{df}=1$, and $p<0.0004$.

\begin{tabular}{|l|c|c|}
\hline & $\begin{array}{l}\text { 500-hPa Relative } \\
\text { Humidity } \mathbf{4 8 \%}\end{array}$ & $\begin{array}{l}\text { 500-hPa Relative } \\
\text { Humidity }<\mathbf{4 8 \%}\end{array}$ \\
\hline $\begin{array}{l}\text { Thunderstorms } \\
\text { Occurred }\end{array}$ & 38 & 25 \\
\hline $\begin{array}{l}\text { No Thunderstorms } \\
\text { Occurred }\end{array}$ & 15 & 48 \\
\hline
\end{tabular}

Table 11. Mean 1200 to 0000 UTC warming at selected levels separated by thunderstorm and non-thunderstorm days from June to September. Data derived from BRO RAOBs.

\begin{tabular}{|c|c|c|}
\hline $\begin{array}{c}\text { Level or Layer } \\
(\mathrm{hPa})\end{array}$ & $\begin{array}{c}\text { 12-h Warming }\left({ }^{\circ} \mathbf{C}\right): \\
\text { Thunderstorm Days }\end{array}$ & $\begin{array}{c}\text { 12-h Warming }\left({ }^{\circ} \mathbf{C}\right): \text { Non- } \\
\text { Thunderstorm Days }\end{array}$ \\
\hline 850 & 0.36 & 1.05 \\
\hline 700 & 0.31 & 0.52 \\
\hline 500 & 0.11 & 0.83 \\
\hline
\end{tabular}

downdrafts from failed cumulus clouds (Wang and Geerts 2013). On thunderstorm days, convection alters temperatures significantly though a deeper layer of the column and may mask the effects of other processes (Yanai and Johnson 1993). Note that Table 11 only shows temperature values at 850-, 700-, and 500-hPa and likely misses the strongest warming that was observed in a very thin layer and smaller temporal window. Conducting tests for independence for days in which $850-\mathrm{hPa}$ temperatures rose $0.4^{\circ} \mathrm{C}$ from 1200 to 0000 UTC returns a $p$ value of 0.001 , as shown in Table 12. This yields very high confidence that these variables are not independent. At $700 \mathrm{hPa}$, the same test (Table 13) produces a $p$ value of 0.031 . This also results in very high confidence that these variables are not independent. As such, it appears that daytime warming in this layer and thunderstorm development are related.

Table 12. Number of thunderstorm and non-thunderstorm days from June to September in which the 1200 to 0000 UTC $850-\mathrm{hPa}$ temperature change was $\geq 0.4 \mathrm{C}$ and $<0.4^{\circ} \mathrm{C}$. Results of Pearson's $\chi^{2}$ test are $\chi^{2}=11.757$, df $=1$, and $p=0.001$. Data from BRO RAOBs.

\begin{tabular}{|c|c|c|}
\hline & $\begin{array}{c}850-\mathrm{hPa} 12-\mathrm{h} \Delta \mathrm{T} \\
\geq 0.4^{\circ} \mathrm{C}\end{array}$ & $\begin{array}{c}\text { 850-hPa 12-h } \Delta \mathrm{TT} \\
<0.4^{\circ} \mathrm{C}\end{array}$ \\
\hline $\begin{array}{l}\text { Thunderstorms } \\
\text { Occurred }\end{array}$ & 27 & 36 \\
\hline $\begin{array}{l}\text { No Thunderstorms } \\
\text { Occurred }\end{array}$ & 46 & 17 \\
\hline
\end{tabular}

Table 13. Same as Table 12 except for the 700-hPa temperature change was $\geq 0.5 \mathrm{C}$ and $<0.5^{\circ} \mathrm{C}$. Results of Pearson's $\chi^{2}$ test are $\chi^{2}=$ 4.63 , $\mathrm{df}=1$, and $p=0.031$.

\begin{tabular}{|l|c|c|}
\hline & $\begin{array}{c}\mathbf{7 0 0 - h P a ~ 1 2 - h} \Delta \mathbf{T} \\
\mathbf{\geq 0 . 5} \mathbf{C}\end{array}$ & $\begin{array}{c}\mathbf{7 0 0 - h P a ~ 1 2 - h} \Delta \mathbf{T} \\
<\mathbf{0 . 5} \text { C }\end{array}$ \\
\hline $\begin{array}{l}\text { Thunderstorms } \\
\text { Occurred }\end{array}$ & 29 & 34 \\
\hline $\begin{array}{l}\text { No Thunderstorms } \\
\text { Occurred }\end{array}$ & 41 & 22 \\
\hline
\end{tabular}

To examine this warming more closely and attempt to diagnose its source, RAOBs from 14 nonthunderstorm days that showed the strongest warming were further analyzed to find the specific location of strongest 1200 to 0000 UTC temperature increases in the $900-700-\mathrm{hPa}$ layer. In all 14 cases, this layer cooled when compared with the previous 0000 UTC sounding, suggesting it was not a result of persistent synoptic-scale subsidence. The average temperature change was $+2.1^{\circ} \mathrm{C}$, with the increase occurring between 850 and $800 \mathrm{hPa}$ in 12 of the cases and near 750 $\mathrm{hPa}$ in the remaining 2 cases. This compares to average warming among the non-thunderstorm dataset of about $1{ }^{\circ} \mathrm{C}$. This warming is greater than what would be expected from the absorption of insolation by water vapor alone (Lacis and Hansen 1974). A contributing factor could be the increased rate at which cumulus clouds absorb solar radiation, but it also is believed to be a result of downdrafts of failed cumulus clouds and/ 
or cumulus clouds warming the surrounding air. Although this warming also likely occurs on thunderstorm days, greater vertical transport of heat via thunderstorm convection may make the signal less obvious. (Yanai and Johnson 1993; Wang and Geerts 2013). The geopotential height of the warming maxima was between $1500 \mathrm{~m}(4900 \mathrm{ft})$ and $2000 \mathrm{~m}$ $(6560 \mathrm{ft})$ in 12 cases and approximately $2500 \mathrm{~m}(8200$ $\mathrm{ft}$ ) in 2 cases. The BRO ASOS recorded clouds starting between 1600 and 1800 UTC in all 14 cases, with cloud bases ranging between $762 \mathrm{~m}(2500 \mathrm{ft})$ and 1371 $\mathrm{m}(4500 \mathrm{ft})$. The average cloud coverage was $40 \%$. For comparison, a search for warm-season days containing a lack of cumulus clouds, subsidence inversions, and persistent large-scale subsidence warming was made. However, no overlap of the two conditions was found during the study. Presumably, this is a result of the consistent near-surface moisture and heating available during the 1 June to 30 September period (Arakawa and Schubert 1974).

Figure 5 shows a scatter plot of 1200 to 0000 UTC 850-hPa temperature change and 1200 UTC 850-700$\mathrm{hPa}$ relative humidity sorted by thunderstorm and nonthunderstorm days. A signal for thunderstorm days to have higher layer relative humidity values is apparent. A correlation coefficient of -0.31 exists between mean $850-500-\mathrm{hPa}$ and $850-700-\mathrm{hPa}$ relative humidity values and 1200 to 0000 UTC warming, suggesting a moderately negative linear relationship (Dancey and Reidy 2004). Very low correlation coefficient values are found when examining 850-hPa 1200 to 0000 UTC warming and relative humidity values, suggesting a strong linear relationship does not exist. The nonlinear relationship is likely due to several factors including the resolution of observational data used, the high degree of variability with which insolation is absorbed by water vapor (Lacis and Hansen 1974), and the effects of cumulus and deep, moist convection on the thermodynamic environment.

\section{b. A case example}

Figures $6 \mathrm{a}-\mathrm{d}$ show the development and dissipation of cumulus clouds at BRO between 1600 and 1615 UTC on 2 September 2013. The ASOS, located at the airport, reported an air temperature of $32.2^{\circ} \mathrm{C}$ $\left(90^{\circ} \mathrm{F}\right)$ and a dewpoint temperature of $23.8^{\circ} \mathrm{C}\left(75^{\circ} \mathrm{F}\right)$ at the time the photographs were taken. The 1200 UTC RAOB (Fig. 7a), taken from the same location and modified for the 1600 UTC temperature and dewpoint, supported positive 100-hPa mixed-layer CAPE (Fig

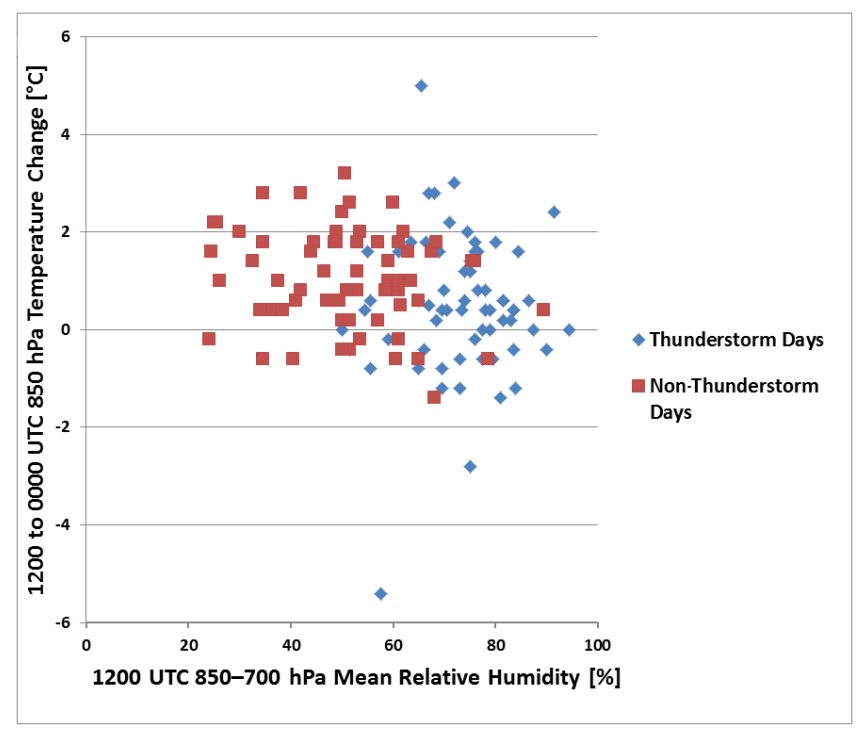

Figure 5. Scatterplot comparing 1200 UTC mean $850-700-\mathrm{hPa}$ relative humidity and $850-\mathrm{hPa} 1200$ to 0000 UTC temperature change for thunderstorm and non-thunderstorm cases.

7b) that simple parcel theory (Holton 2004) suggests would produce deep, moist convection. No thunderstorms occurred on this day.

Despite rich boundary layer moisture, the 1200 UTC RAOB (Fig. 7a) showed a rapid drying at 682 $\mathrm{hPa}$, where relative humidity values fell to $42 \%$. Atmospheric lapse rates between $900-700 \mathrm{hPa}$ were $5.8^{\circ} \mathrm{C} \mathrm{km}^{-1}$. Average cloud base heights around 1400 $\mathrm{m}$ (4600 ft) were reported by the ASOS during the 15min period in which the pictures were taken. It appears in the photos that an ensemble of cumulus clouds of varying height developed below the layer of drying, with some cumuli likely penetrating into that layer. This process can be seen in Figs. 6a-d. The initial cumulus, labeled "A," warmed the surrounding air as it ascended, became negatively buoyant, and dissipated (presumably after entraining drier air). This cloud, similar to any developing and failing cumulus cloud, also would have produced a weak downdraft, which warms by compression (Wang and Geerts 2013). In addition, parcels that have already encountered and entrained surrounding air also would warm. Cloud "B" modified its environment as well and encountered environmental air modified by previously developing and dissipating cumulus clouds. The parcel then became neutrally buoyant, detrained, and generated additional subsidence in the form of a downdraft. The process repeated, warming a shallow layer via an ensemble of clouds. Ascending clouds then encountered drier environmental air and became negatively buoyant. 


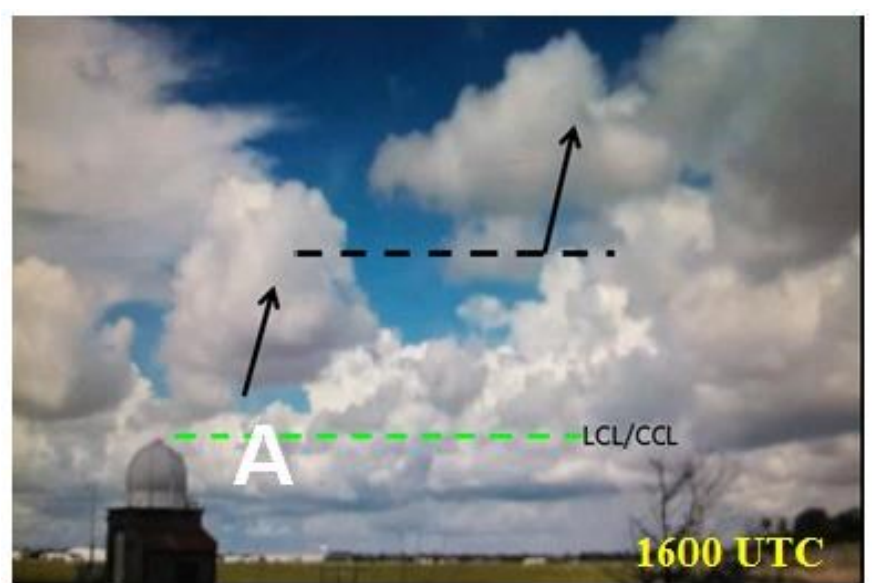

(a)

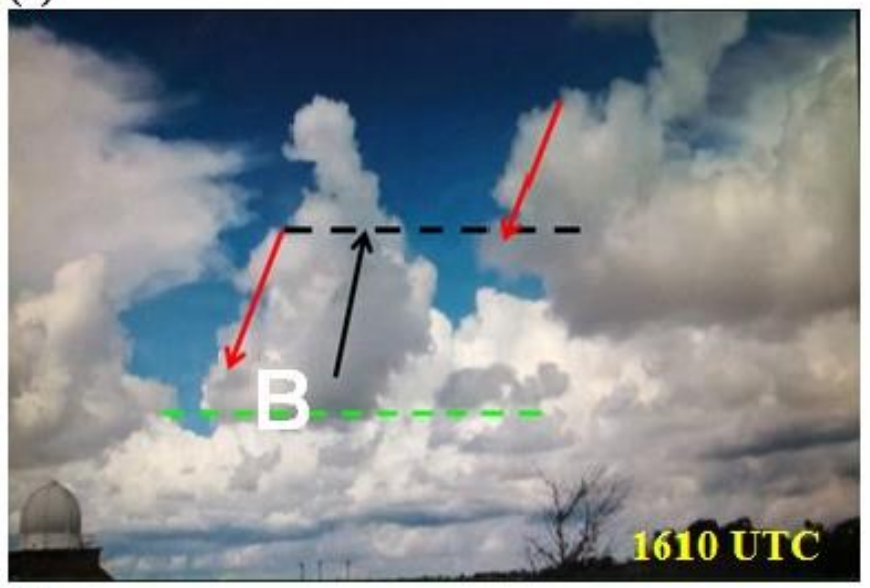

(c)

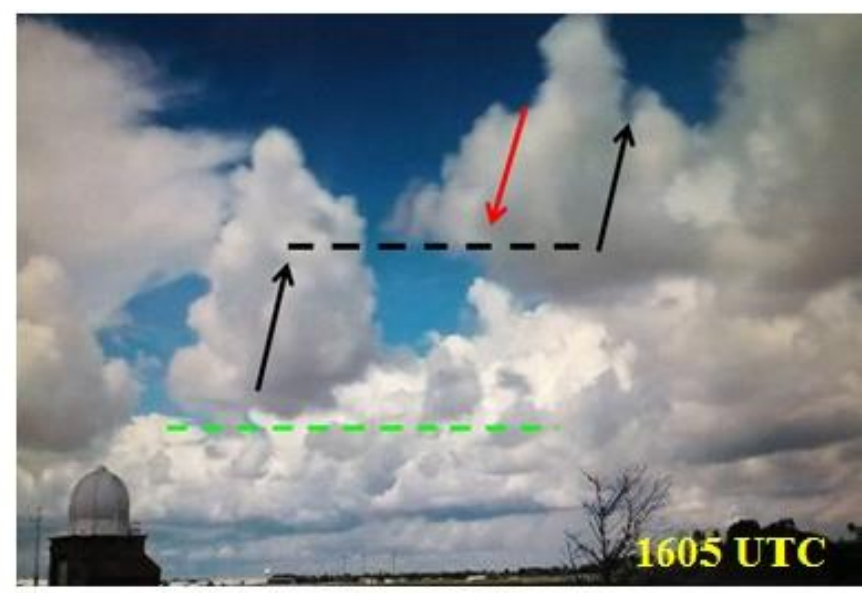

(b)

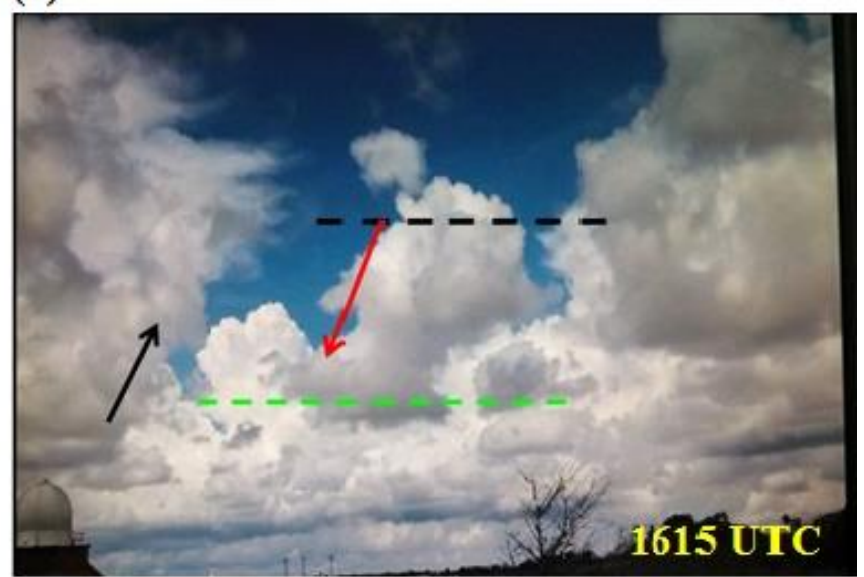

(d)

Figure 6. Time sequence of photographs showing cumulus cloud development at the Brownsville/South Padre Island International Airport beginning approximately 1600 UTC 2 September 2013. Black (red) arrows denote the estimated location of updrafts (downdrafts) responsible for cumulus development. Approximate height of the lifting condensation level is indicated by a green dashed line, and the black dashed line indicates the approximate location at which the updraft of leftmost cumulus cloud dissipates. Approximate times of photographs are (a) 1600 UTC, (b) 1605 UTC, (c) 1610 UTC, and (d) 1615 UTC.

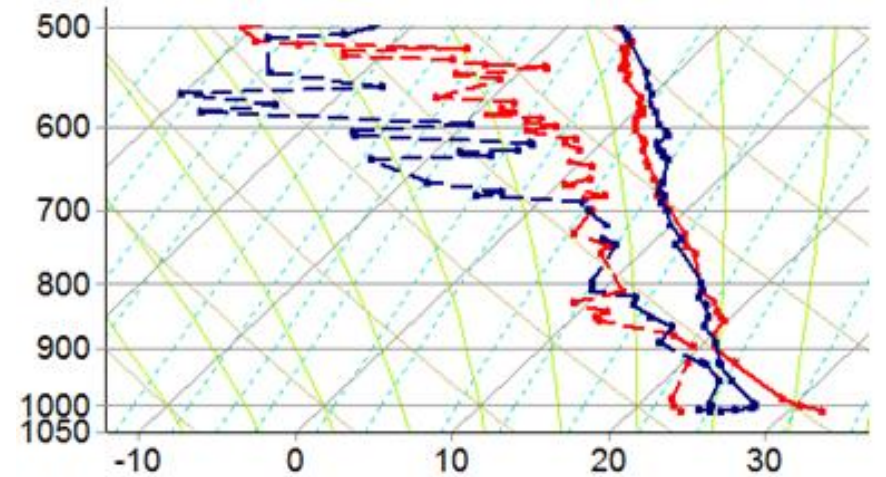

(a)

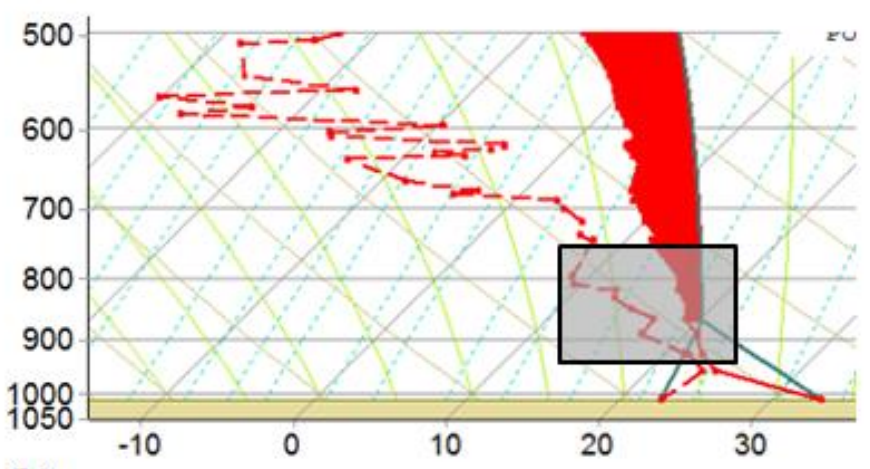

(b)

Figure 7. Skew $T-\log p$ thermodynamic diagrams from the surface to $500 \mathrm{hPa}$ for 2 September 2013 , the day of the photo sequence shown in Fig. 6. (a) The 1200 UTC (colored blue) BRO RAOB for 2 September is compared to the 0000 UTC (colored red) BRO RAOB for 3 September. (b) 1200 UTC sounding for 2 September, modified for the day's observed maximum temperature. The theoretical parcel line and CAPE are shown. A layer of warming and drying above the lifted condensation level is shaded in gray. Data courtesy of University of Wyoming. 
The effect of this process is visible in Fig. 7a. A small amount of warming and drying is visible near $850 \mathrm{hPa}$. Between 1200 and 0000 UTC, the geopotential height of $850 \mathrm{hPa}$ showed almost no variation. The temperature rose $0.8^{\circ} \mathrm{C}$, and the dewpoint temperature fell $1.6^{\circ} \mathrm{C}$. These results are supported by observational studies conducted by Yanai and Johnson (1993), as well as parameterized modeling experiments conducted by Derbyshire et al. (2004) and Sui et al. (1989). This amount of warming, usually between 0.8 and $2{ }^{\circ} \mathrm{C}$, exceeds what is expected from insolation alone (Lacis and Hansen 1974) and may be sufficient to render surface-based parcels either statically stable or only unstable enough to produce additional non-precipitating cumulus clouds, despite increasing surface heating.

\section{Conclusions}

This study associated increased relative humidity values at 850,700 , and $500 \mathrm{hPa}$ with a higher occurrence of thunderstorms in the Lower Rio Grande Valley between 1 June and 30 September. Data suggest the vast majority of thunderstorms in the Lower Rio Grande Valley that form during this time period do so amid weak synoptic-scale forcing, making skilled forecasts challenging. Other meteorological variables (e.g., wind shear, lapse rates, surface temperature, and dewpoint) showed no statistically significant variability between warm-season days that thunderstorms were reported and days they were not in the region's subtropical climate.

The relationship of mid-tropospheric relative humidity to thunderstorm development is believed to be a product of the role of entrainment in updraft buoyancy (Holton 2004) amid weak atmospheric lapse rates. When relative humidity values remain high through a deeper layer of the atmosphere, rising cumulus clouds entrain less dry air during their ascent (de Rooy et al. 2013). The result is a higher rate of condensation, which keeps the parcel lapse rate low (Holton 2004). This makes a close analysis of the depth of atmospheric moisture in the lower free troposphere critical in forecasting summertime thunderstorms in the Lower Rio Grande Valley. Persistent synoptic-scale subsidence keeps lapse rates weak in the 850-500-hPa layer above the Lower Rio Grande Valley during the months included in this study. Intraseasonal shifts of the intertropical convergence zone can result in increased influence from African easterly waves and periodic higher values of relative humidity in a deep layer
(Maloney and Shaman 2008), which can lead to higher rates of thunderstorm activity over the area. Further, when developing convection is more vigorous, stronger convergence and entrainment are generated near the cloud base. Assuming a conditionally unstable environment, the resultant deep, moist convection would produce stronger downdrafts that would provide sufficient low-level convergence for new updrafts (Wilhelmson and Chen 1982). This makes additional thunderstorms more likely once the first thunderstorm develops.

Cumulus clouds that encounter drier air on ascent entrain that drier air and tend to become neutrally to negatively buoyant amid the poor environmental lapse rates (Holton 2004). These failed cumulus clouds and their downdrafts appear to warm a thin layer within the 900-700-hPa layer (Yanai and Johnson 1993) between 0.5 and $2^{\circ} \mathrm{C}$, which may further act to limit new updrafts when combined with the existing weak lapse rates and low relative humidity. Downdrafts may also penetrate the boundary layer and inject drier air, which is mechanically mixed to the surface (Yanai and Johnson 1993). This can further hinder surface-based instability.

Operational forecasters in the Lower Rio Grande Valley are encouraged to monitor $850-700-\mathrm{hPa}$ relative humidity in both observational data and numerical guidance during the June-September period as part of their forecast routine. Doing so should provide advantages in terms of forecast reliability and may aid in developing confidence of both timing the onset of convection and its coverage across the region, especially when compared with other variables that show little day-to-day variability. An opportunity to forecast dry weather also may exist when lower relative humidity values can be diagnosed or anticipated.

Acknowledgments. The authors thank the entire team at National Weather Service Brownsville, and Robert Ballard of National Weather Service Honolulu, HI, for discussing their observations and challenges in forecasting warm-season thunderstorms, as well as their insight and support during this study, and the JOM editors and reviewers who provided valuable feedback that greatly improved this manuscript.

\section{REFERENCES}

Arakawa, A., and W. H. Schubert, 1974: Interaction of a cumulus cloud ensemble with the large-scale environment, Part I. J. Atmos. Sci., 31, 674-701, CrossRef. 
Byers, H. R., and R. R. Braham, 1949: The Thunderstorm: Final Report of the Thunderstorm Project. U. S. Government Printing Office, 287 pp., CrossRef.

Cotton, W. R., and G. J. Tropoli, 1978: Cumulus convection in shear flow-Three-dimensional numerical experiments. J. Atmos. Sci., 35, 1503-1521, CrossRef.

Dancey, C. P., and J. Reidy, 2004: Statistics without Maths for Psychology. Prentice Hall, 612 pp.

de Rooy, W. C., and Coauthors, 2013: Entrainment and detrainment in cumulus convection: An overview. Quart. J. Roy. Meteor. Soc., 139, 1-19, CrossRef.

Derbyshire, S. H., I. Beau, P. Bechtold, J.-Y. Grandpeix, J.M. Piriou, J.-L. Redeslperger, and P. M. M. Soares, 2004: Sensitivity of moist convection to environmental humidity. Quart. J. Roy. Meteor. Soc., 130, 3055-3079, CrossRef.

Doswell, C. A., III, and P. M. Markowski, 2004: Is buoyancy a relative quantity? Mon. Wea. Rev., 132, 853863, CrossRef.

Grant, A. L. M., 2001: Cloud-base fluxes in the cumuluscapped boundary layer. Quart. J. Roy. Meteor. Soc., 127, 407-421, CrossRef.

Hinkleman, L. M., B. Stevens, and K. F. Evans, 2005: A large-eddy simulation study of anisotropy in fairweather cumulus cloud fields. J. Atmos. Sci., 62, 21552171, CrossRef.

Holton, J. R., 2004: An Introduction to Dynamic Meteorology. 4th ed. Academic Press, 535 pp.

Hopsch, S. B., C. D. Thorncroft., and K. R. Tyle, 2010: Analysis of African easterly wave structures and their role in influencing tropical cyclogenesis. Mon. Wea. Rev., 138, 1399-1419, CrossRef.

Jacovides, C. P., and T. Yonetani, 1990: An evaluation of stability indices for thunderstorm prediction in greater Cyprus. Wea. Forecasting, 5, 559-569, CrossRef.

Kalnay, E., 2003: Atmospheric Modeling, Data Assimilation and Predictability. Cambridge University Press, $369 \mathrm{pp}$.

Keyser, D., M. J. Reeder, and R. J. Reed, 1988: A generalization of Petterssen's frontogenesis function and its relation to the forcing of vertical motion. Mon. Wea. Rev., 116, 762-781, CrossRef.

Lacis, A. A., and J. Hansen, 1974: A parameterization for the absorption of solar radiation in the earth's atmosphere. J. Atmos. Sci., 31, 118-133. CrossRef.
Maloney, E. D., and J. Shaman, 2008: Intraseasonal variability of the west African monsoon and Atlantic ITCZ. J. Climate, 21, 2898-2918, CrossRef.

NOAA, cited 2014: Climate NOWData. National Weather Service. [Available online at www.nws.noaa.gov/ climate/xmacis.php?wfo=bro.]

, cited 2015a: NOAA Monthly Climate Data Product (CF6). National Weather Service. [Available online at www.nws.noaa.gov/climate/index.php?wfo=bro.] , cited 2015b: NWS Performance Management. National Weather Service. [Available online at verification.nws.noaa.gov.]

Rao, C. R., 2002: Karl Pearson chi-square test: The dawn of statistical inference. Goodness-of-Fit Tests and Model Validity, C. Huber-Carol, N. Balakrishnan, M. S. Nikulin, and M. Mesbah, Eds., Birkhäuser, 9-24, CrossRef.

Rinehart, R. E., 1997: Radar for Meteorologists. 3rd ed. Rinehart Publishers, 428 pp.

Siebesma, A. P., 1998: Shallow cumulus convection. Buoyant Convection in Geophysical Flows, E. J. Plate, E. E. Fedorovich, D. X. Viegas, and J. C. Wyngaard, Eds., Kluwer Academic Publishers, 441-486, CrossRef.

Sui, C.-H., M.-D. Cheng, X. Wu, and M. Yanai, 1989: Cumulus ensemble effects on the large-scale vorticity and momentum fields of GATE. Part II: Parameterization. J. Atmos. Sci. 46. 1609-1629, CrossRef.

Vincent, B. R., L. D. Carey, D. Schneider, K. Keeter, and R. Gonski, 2003: Using WSR-88D reflectivity data for the prediction of cloud-to-ground lightning: A central North Carolina study. Natl. Wea. Dig., 27, 35-44. [Available online at www.nwas.org/digest/papers/2003/ Vol27No1/Pg35-Vincent.pdf.]

Wang. Y., and B. Geerts, 2013: Composite vertical structure of vertical velocity in nonprecipitating cumulus clouds. Mon. Wea. Rev., 141. 1673-1692, CrossRef.

Wilhelmson, R. B., and C.-S. Chen, 1982: A simulation of the development of successive cells along a cold outflow boundary. J. Atmos. Sci., 39, 1466-1483, CrossRef.

Yanai, M., and R. H. Johnson, 1993: Impacts of cumulus convection on thermodynamic fields. The Representation of Cumulus Convection in Numerical Models, $\mathrm{K}$. A. Emanuel and D. J. Raymond, Eds., Amer. Meteor. Soc., 39-62. 